\title{
Bibliometric Analysis of Domestic Human Library Research Based on CSSCI Source Journal Articles
}

\author{
Chang Wang* \\ Faculty of Information Management \\ Shanxi University of Finance and Economics \\ Taiyuan, China
}

\author{
Jianhua Han \\ Faculty of Information Management \\ Shanxi University of Finance and Economics \\ Taiyuan, China
}

\author{
Mei Sun \\ Library \\ Shanxi University of Finance and Economics \\ Taiyuan, China
}

\begin{abstract}
Academic circles in Libraries had produced abundant research outcomes on the human library, which is a new service mode. A bibliometric analys is can reveal the rese arch hotspots and development direction of the study in the field of human library, thus providing references to the relevant theoretical research and practical exploration. This paper conducted a bibliometric analys is of the literature on the human library from 2009 to 2018 by retrieving CSSCI Journal in terms of the distribution of time and subject, core authors, source journals, most cited articles, etc. Besides, it drew the co-occurrence knowledge map of high-frequency keywords with CiteSpace. In conclusion, Human Library Research tends to be saturated in China. Current rese arches mainly focused on service mode innovation, reading promotion, reading therapy, as well as the development and application of reader resources. With the transformation of scientific research paradigm, future research will focus on topics including the transfer of implicit knowledge, community library, information ethics, etc.
\end{abstract}

Keywords-Human Library; Living Library; Bibliometric; CSSCI Journal; Knowledge Map

\section{INTRODUCTION}

In the early 1990s, five Danish young people including Ronnie Berger founded an organization of stopping violence and were invited to host the world's first audience interaction called "Living Library" at the Nordic Roskilde Music Festival in July 2000. Seventy-five "Living Books" were lent on the spot to advocate opposing violence, encouraging dialogue, eliminating prejudice and establishing harmonious relations. The interactive activity of peer education had a good effect on society and received many positive comments.

In April 2008, Professor Zeng Lei, a Chinese-American library science expert, introduced the service concept advocated by Living Library to her counterparts in China. As a result, the theme "human library" has been concerned and widely disseminated by the Chinese library community and other related fields. Due to copyright disputes, in January 2010, the Human Library official organization replaced the original name "Living Library" with "Human Library", but China continued to use the "Living Library". So far, scholars have published five bibliometric papers related to the theme on the CNKI in China. Reference[1-3] made quantitative statistical analyses of papers published in China on human library, including the distribution of time, journal source, authors, hotspots, fund projects funding, citations and downloads, research topics, etc. Reference[4] conducted a visual analysis based on knowledge maps of the theme, and it consisted of age distribution, representative authors and their institutions, research hotspots, and research frontiers. Reference[5] visualized relevant papers from three dimensions: journal distribution, author distribution, and hotspots distribution, and used computer programs like CiteSpace, SATI, and VOS viewer as measurement and data processing tools.

According to the existing papers: in the time span, previous research results ended in March 2015, and the latest research results have not been reflected in the past three years in this field; in terms of database sources, previous studies have used the total library literature or journal papers in CNKI as the data source, and there is no research on literature published in core journals. According to the stacking effect of literature distribution and the Bradford literature decentralization law, the core journals are journals with many papers in the subject area, high-quality papers and strong academic influence. Consequently, in order to reflect the research hotspots and trends of the authoritative scholars in the field, especially in the past three years, this paper conducts a quantitative analysis of the CSSCI journal papers in the field of human library from 2009 to 2018 in China, aiming to reveal the research status and development direction and provide references for the theoretical research and practical exploration on this theme.

\section{DATA SOURCE AND RESEARCH METHODS}

This paper used the CSSCI source journal (including extended version) papers in CNKI journal database as the data source. It took "human library" or "living library" or "borrowing activities" or "library borrowing activities" as the theme and took "human books" or "living books" as keywords for retrieving accurately. Until June 30, 2018, 161 papers were retrieved. Through screening manually, eliminating the incomplete information of the title and non-academic literature, 
155 valid documents were obtained. The following are the specific processing.

Firstly, the writer exported the 155 valid documents to Excel software and obtained some relevant data like authors, titles, periodical name, and volumes. Secondly, the writer organized, carried out statistics, and analyzed bibliometrically the data by using functions such as sorting, screening, classifying, and graphing. Next, the 155 valid documents were exported in Refwork format. Then, the writer used CiteSpace to convert them into its identifiable Wos format. Lastly, the writer drew a keyword co-occurrence knowledge map and visualized the research hotspots.

\section{RESULT ANALYSIS}

\section{A. Time Distribution}

It is possible to evaluate and predict the research level, development status and trends of a discipline or field by statistically analyzing its quantitative relationship of relevant literature for a while [6]. Fig. 1 shows the time distribution of number of papers published by CSSCI source journals (including extended editions) on human library from 2009 to the first half of 2018 in China.

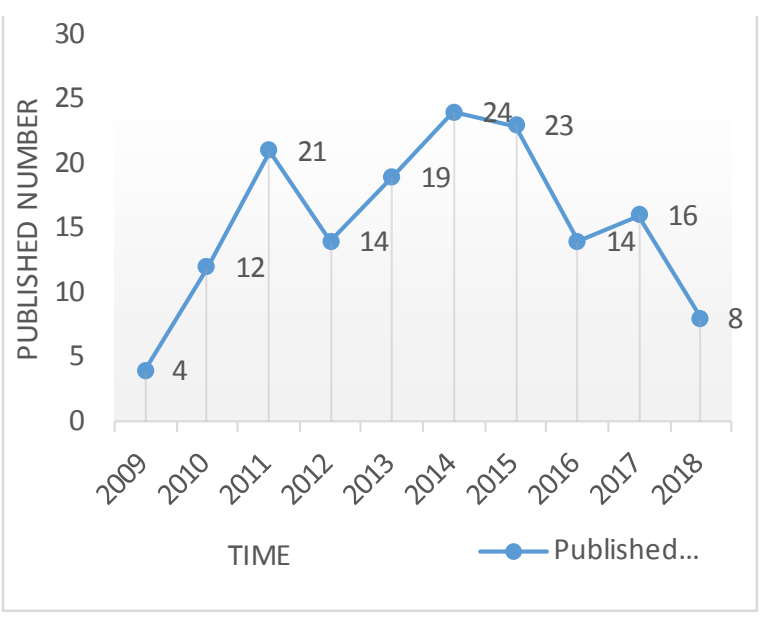

Fig. 1. Time Distribution

As we can see, the first CSSCI literature on human library was published in 2009, and the number of publications increased later, marking the formation of the discipline. According to Fig. 1, it can be roughly divided into four stages: Germination stage (2009 2010), which was the introduction stage. The research in this field has begun to attract attention, and the overall results were less; Shock development stage (2010 2012) was the exploration stage. The number of outcomes increased and decreased, and the development was not stable; Maturity stage (2012 2015) was the rapid development stage. It was stable at around 20 basically; Differentiation and decay stage (2015 2017), the amount of CSSCI issued decreased, but it remained at a certain level. On the whole, this field has attracted the attention of academic circles and experienced the historical process of birth, development, maturity and differentiation in the past decade. During the first seven years of full-scale research and vigorous development, the number of documents has risen sharply and has begun to penetrate into other areas. In the past three years, the related research literature has slowed down in growth rate and has become saturated, but there is no indication that the research will enter a recession or even stagnate. In the context of the current scientific research paradigm shift, the human library will change or differentiate in the process of introducing new theories, methods, technologies and tools, and will usher in a new stage of development.

\section{B. Discipline Distribution}

Exploring the discipline distribution of human library in CSSCI can clarify its degree of attention by different disciplines and demonstrate the role played by related disciplines. Among the valid papers, 146 papers belong to the library and information science, accounting for $94.19 \%$, which indicate that the discipline is the main research force; There are 8 papers from computer application discipline, accounting for $5.16 \%$; Only one belongs to foreign language and writing subject, accounting for $0.65 \%$. Fig.2 shows that the research on human library has infiltrated and crossed with computer application but have not yet formed a certain relationship with other disciplines.

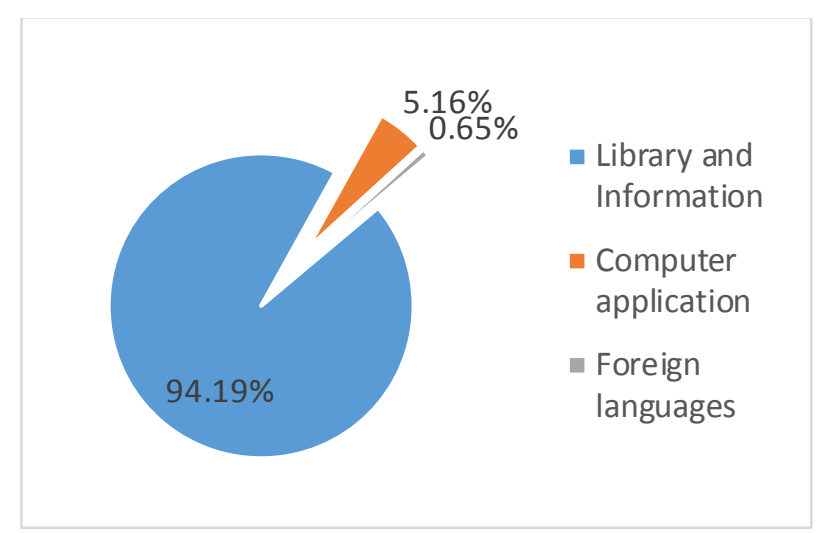

Fig. 2. Discipline Distribution

\section{Core Authors}

Price's law states that papers published by high-yielding authors should account for half of the total in a field, and the minimum number of papers issued by core authors should be

$$
m \approx 0.749 \sqrt{n \max }
$$

$n \max$ is the number of papers produced by the most productive authors [7]. In the retrieved literature, $n \max =5$, so the core author should have a minimum of 1.7 papers. According to statistics, the number of papers published by 32 authors is larger than 2. 32 authors published 54 papers, accounting for $34.84 \%$, obviously, it is far from the $50 \%$ of the total number, revealing that human library field in China has not yet formed a mature core author group. Further researching, there are 49 articles belonging to the co-authored literature,2 writers wrote 33 papers together, 3 authors collaborated on 10 , 4 persons wrote 5 articles together and 5 writers collaborated on 1 . The coauthor rate was $31.61 \%$, indicating that the 
academic research and cooperation has not yet reached a certain depth in this field. The authors who published more than 2 papers and whose papers were cited as more than 30 times were presented in TABLE I.

TABLE I. PARTIAL CORE AUTHOR ST ATISTICS

\begin{tabular}{|c|c|c|}
\hline Authors & $\begin{array}{c}\text { Number } \\
\text { of papers } \\
\text { published }\end{array}$ & Institutions \\
\hline Wan Wenjuan & 5 & Guangxi Normal University \\
\hline Nan Aifeng & 3 & Yantai University \\
\hline Wang Peilin & 3 & Anhui University \\
\hline Liu Shirong & 3 & $\begin{array}{c}\text { Hunan University of Humanities, } \\
\text { Science and Technology }\end{array}$ \\
\hline Zeng Ting & 3 & $\begin{array}{c}\text { Wuhan University/ } \\
\text { Wuhan Land Resources and } \\
\text { Planning Information Center }\end{array}$ \\
\hline Xu Jing & 2 & Shanghai Jiao Tong University \\
\hline Su Haiyan & 2 & Shijiazhuang University \\
\hline $\begin{array}{c}\text { Wang Junxue, } \\
\text { Song Xinhua }\end{array}$ & 2 & \begin{tabular}{c} 
Qingdao University \\
\hline Wu YunShan
\end{tabular} \\
\hline $\begin{array}{c}\text { Ke Danqian, } \\
\text { Wu Yuewei, } \\
\text { Dong Ke }\end{array}$ & 2 & Guangxi Normal University \\
\hline Xiong Taichun & 2 & $\begin{array}{c}\text { Wuhan Documentation and } \\
\text { Information Center/ } \\
\text { Wuhan University }\end{array}$ \\
\hline
\end{tabular}

\section{Journal Sources Distribution}

According to statistical analysis, 155 papers retrieved were derived from 20 journals, as shown in TABLE II. Except for the Journal of Southwest Minzu University(Humanities and Social Sciences) and Heilongjiang National Series, the remaining 18 kinds belong to library and information publications. Among them, there are 11 periodicals with more than 5 papers, publishing 137 papers, which accounts for $88 \%$. It demonstrates that these CSSCI journals are the main platforms to publish articles on human library in China.

\section{E. Fund Project}

The number of literature funded by fund project in a certain field and the situation that the national fund supports a certain topic are regarded as one of the indicators to measure the attention degree in a research field. The fund project funding about 155 articles retrieved is shown in TABLE III.

TABLE III shows 13 papers funded by the fund project, accounting for $8.39 \%$. Among them, 6 papers were funded by national funds and 7 were funded by provincial funds. Papers in this field have attracted increasing attention and support from national departments, provincial departments, experts and scholars since 2016. From Table IV, we can find that, in generally, human library field is less supported by fund. Scholars in this field should strive for the initiative of fund projects and devote themselves to propose more innovative research topics.

\section{F. Highly cited literature analysis}

The citation frequency of the literature is one of the criteria for judging the quality of the literature. The higher citations frequency, the higher academic value, the greater academic influence of the author, and the stronger influence of the periodicals. The highly cited literatures not only establish a knowledge foundation, but also provide reference for future researches in this field. Table IV shows statistical analysis on the highly cited papers that have been cited more than 30 times on human library in the past 10 years.

TABLE II. JOURNAL SOURCE DISTRIBUTION

\begin{tabular}{|c|c|c|c|}
\hline Journal Title & $\begin{array}{l}\text { Published } \\
\text { Number }\end{array}$ & Journal Title & $\begin{array}{l}\text { Published } \\
\text { Number }\end{array}$ \\
\hline $\begin{array}{l}\text { Library Work and } \\
\text { Study }\end{array}$ & 22 & $\begin{array}{c}\text { Journal of Academic } \\
\text { Libraries }\end{array}$ & 6 \\
\hline $\begin{array}{c}\text { Library } \\
\text { Development }\end{array}$ & 19 & Information Science & 4 \\
\hline $\begin{array}{c}\text { Modern } \\
\text { Information }\end{array}$ & 14 & Library \& Information & 3 \\
\hline $\begin{array}{l}\text { Library and } \\
\text { Information } \\
\text { Service }\end{array}$ & 14 & $\begin{array}{c}\text { Journal of the National } \\
\text { Library of China }\end{array}$ & 2 \\
\hline Library Journal & 11 & Journal of Intelligence & 1 \\
\hline Library Tribune & 10 & $\begin{array}{l}\text { Information Studies: } \\
\text { Theory \& Application }\end{array}$ & 1 \\
\hline $\begin{array}{c}\text { Researches In } \\
\text { Library Science }\end{array}$ & 9 & $\begin{array}{cl}\text { Information } \text { and } \\
\text { Documentation Services }\end{array}$ & 1 \\
\hline Library & 9 & $\begin{array}{c}\text { Journal of Southwest } \\
\text { Minzu University } \\
\text { (Humanities and Social } \\
\text { Science) }\end{array}$ & 1 \\
\hline $\begin{array}{c}\text { Library Theory } \\
\text { and Practice }\end{array}$ & 8 & $\begin{array}{c}\text { Heilongjiang National } \\
\text { Series }\end{array}$ & 1 \\
\hline
\end{tabular}

TABLE III. FUND PROJECTS

\begin{tabular}{|c|c|c|c|c|c|}
\hline $\begin{array}{c}\text { Papers } \\
\text { Number }\end{array}$ & $\mathbf{2 0 1 0}$ & $\mathbf{2 0 1 4}$ & $\mathbf{2 0 1 6}$ & $\mathbf{2 0 1 7}$ & $\mathbf{2 0 1 8}$ \\
\hline Fund project & 1 & & 2 & 2 & \\
\hline National Social Science Fund & 1 & & 1 & & \\
\hline $\begin{array}{l}\text { Nutional Study Abroad Fund } \\
\text { Science Fund }\end{array}$ & & & & 3 & 1 \\
\hline $\begin{array}{l}\text { Fujian Provincial Education } \\
\text { Commission Research Fund }\end{array}$ & & 2 & & & \\
\hline $\begin{array}{l}\text { Jiangsu Provincial Department } \\
\text { of Education Humanities and } \\
\text { Social Sciences Research Fund }\end{array}$ & & & & 1 & \\
\hline
\end{tabular}

As can be seen from Table IV, reference [7] has been cited 99 times. The author illustrated the development status and social significance of Living Library at home and abroad, and he also analyzed the enlightenment brought by the service innovation of university library based on the five characteristics of Living Library in detail. It has a very high academic value, leading the research boom of human library. Reference [8] has been cited 92 times. This paper pointed out that reader resources are implicit and decentralized, and it is difficult to develop. Human library is a typical example of effectively developing readers' knowledge resources. This article has led the later scholars to study the human books as a kind of knowledge resource. Reference [9] ranking third, introduced the Living Library activity in Shanghai Jiao Tong University and proposed that Living library can be incorporated into the subject service of university libraries as a normal service; it provides a classic research mode to conduct living library activities for various libraries. Looking at the 14 high-cited documents listed in Table IV, we can find that the 
research hotspots in human library focus on topics such as service mode innovation, tacit knowledge management, reading therapy, virtual community construction, etc. Meanwhile, they are valued and applied by other scholars respectively.

TABLE IV. HIGHLY PARTIAL CITED LITERATURE MORE THAN 30 TIMES

\begin{tabular}{|c|c|c|c|}
\hline Sequences & Titles & $\begin{array}{c}\text { Cited } \\
\text { Frequency }\end{array}$ & Sources \\
\hline 1 & $\begin{array}{l}\text { The enlightenment of } \\
\text { Living Library to } \\
\text { university library service } \\
\text { innovation }\end{array}$ & 99 & $\begin{array}{l}\text { Journal of } \\
\text { Academic } \\
\text { Libraries }\end{array}$ \\
\hline 2 & $\begin{array}{lr}\text { A new } & \text { mode for } \\
\text { developing } & \text { readers' } \\
\text { knowledge } & \text { resources: } \\
\text { Living Library } & \\
\end{array}$ & 92 & $\begin{array}{l}\text { Library } \\
\text { Journal }\end{array}$ \\
\hline 3 & $\begin{array}{l}\text { The innovation of } \\
\text { subject knowledge } \\
\text { service in university } \\
\text { libraries-Taking } \\
\text { Shanghai Jiao tong } \\
\text { University Library as an } \\
\text { example }\end{array}$ & 78 & $\begin{array}{l}\text { Library and } \\
\text { Information } \\
\text { Service }\end{array}$ \\
\hline 4 & $\begin{array}{l}\text { Living Library: Another } \\
\text { window for library } \\
\text { reader service }\end{array}$ & 70 & $\begin{array}{l}\text { Library } \\
\text { Develop me } \\
\text { nt }\end{array}$ \\
\hline 5 & $\begin{array}{l}\text { Research on the status, } \\
\text { problems and } \\
\text { countermeasures of } \\
\text { Human Library in China }\end{array}$ & 67 & $\begin{array}{l}\text { Library } \\
\text { Develop me } \\
\text { nt }\end{array}$ \\
\hline 6 & $\begin{array}{l}\text { A Study on the develop } \\
\text { ment overview of } \\
\text { Human Library }\end{array}$ & 56 & $\begin{array}{l}\text { Library and } \\
\text { Information } \\
\text { Service }\end{array}$ \\
\hline 7 & $\begin{array}{l}\text { A brief discussion on the } \\
\text { new service mode of the } \\
\text { library: "Living Lib rary" } \\
\text { ("Library Borrowing } \\
\text { Activities") }\end{array}$ & 55 & $\begin{array}{l}\text { Library } \\
\text { Tribune }\end{array}$ \\
\hline 8 & $\begin{array}{l}\text { Human Library creates a } \\
\text { new mode of individual } \\
\text { tacit knowledge } \\
\text { management in library }\end{array}$ & 46 & $\begin{array}{l}\text { Library and } \\
\text { Information } \\
\text { Service }\end{array}$ \\
\hline
\end{tabular}

\section{G. Content Analysis}

Keywords are the author's summary of the literature content Through the statistical analysis of keywords' co-occurrence, the research hotspots can be reflected intuitively in a certain subject area and the development trend can be predicted accordingly. Eliminating the no inductive meaning of "Human Library", "Living Library", and "Library borrowing activities", the writer draws a knowledge map of co-occurrence keywords that appeared 2 times or more in 155 papers by CiteSpace, as shown in Fig. 3. Each node in the figure represents a keyword, the size of the node represents the occurrence frequency of the keyword, and the thickness of the connection between nodes represents the total number of citations of the keywords. Among them, the nodes with apertures like "university library" and "library" have high centrality and are closely related to other nodes such as "reading promotion", "service innovation", "subject service", "reader service", "reading therapy", "tacit knowledge" and "resource construction".

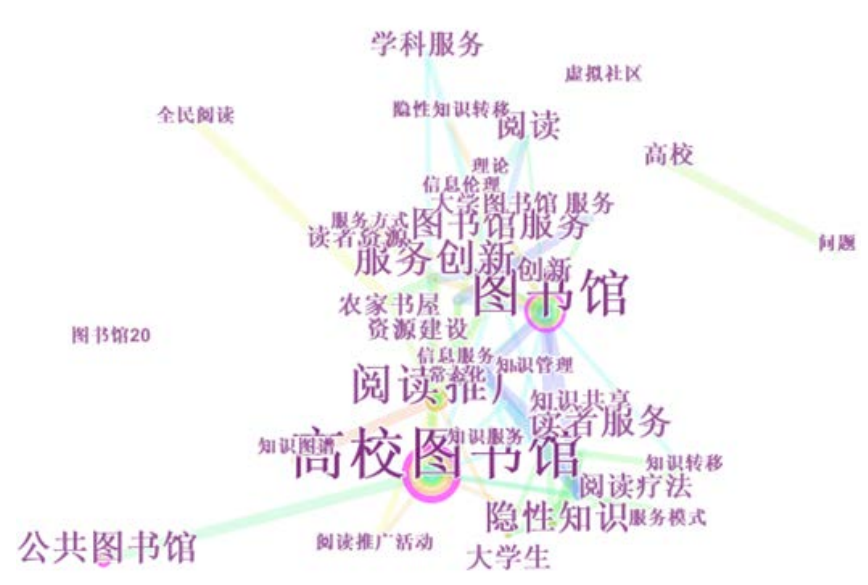

Fig. 3. Co-occurrence knowledge map of key words

\section{1) Hot topics}

The theme of Fig. 3. is divided and the research hot spots are summarized as follows:

\section{a) Subject and object of activity}

"Library”, "University Library" and "Public Library" are high-frequency keywords and have a high centrality. It shows that the subjects of hosting human library activities are various libraries mainly. The university library has rich educational resources and strong scientific research capability, thus becoming the first major subject. Although the time to carry out human library activities is relatively late, the public library is an active explorer of the practice. In addition, with the characters of inclusiveness, openness, and public welfare, as a result, it has become the second largest subject of human library activities. Besides, in contrast to previous studies, it is found that "colleges" and "college students" (keyword statistics are 3 and 4 respectively) are presented in the knowledge map in a higher frequency, which reflects that the human library research tends to solve problems faced by undergraduates and colleges.

\section{b) Service model innovation}

Keywords related to this topic include "service innovation", "library services”, "reader services”, “disciplinary services”, "information services", "service models" and so on. From the traditional perspective, libraries provide readers with paper resources and electronic resources. When using resources, readers use one-way access to knowledge through retrieving and reading. Additionally, readers can't communicate with resource creators directly. Questions arising from reading cannot be answered immediately. While the human library has realized the innovation of the service mode through the interactive communication between readers and human books. In the process of reading, the reader's doubts not only can get replied timely but also it is likely to have a resonance of thought or a spark of wisdom between the two sides, which will promote reading. This mode satisfies the reading needs of readers to confide themselves in modern society and innovates the mode of subject service provided by librarians from waiting passively to supplying proactively. 


\section{c) Reading promotion}

Keywords related to this theme are "reading", "reading promotion activities", "national reading" and "farm bookstore", which shows that the farm bookstore has become an important platform for reading promotion. In the two sessions of the National People's Congress this year, promoting reading and improving reading conditions for the whole people have become a hot topic once again for the deputies. Reading promotion is an important reading service to the public. Every member of society is not only the object of reading promotion but also its promoters. Reading promotion is a new service and natural mission of modern libraries. As a new form of reading promotion, the human library is an innovation of library reading concepts and practices [10]. Reading people is reading books, and the unique mental process of human books can be read. In the age of knowledge explosion, the way to read and communicate face to face between human books and readers is the sublimation of traditional paper reading and electronic reading, it not only meets the practical needs of exchanging and sharing for readers but also injects fresh blood into the reading promotion activities.

\section{d) Reading therapy}

In the third edition of the Webster's New International English Dictionary, reading therapy is defined as:1) Assisting medical and psychiatric treatment with selective reading materials; (2) Help solve personal problems through guided reading. Traditional reading therapy uses books and literature as a tool for assisting treatment, guiding readers to learn, understand, comprehend books and literature content, achieving the effect of calming emotions and restoring the normal psychological state for readers. The personalized customization service provided by the human library helps the successful implementation of reading therapy. On the one hand, readers can choose a human book with similar life circumstance to themselves, which can generate resonance through communication, release negative emotions, cope with stress. On the other hand, after understanding the solutions to the problem of human books, readers can achieve self-reflection, self-adjustment, self-understanding, and thus achieving emotional healing.

\section{e) Development and application of reader resource}

Keywords related to this topic are "reader resources", "resource construction", and "knowledge sharing". The British philosopher Michael Polanyi believes that the knowledge possessed by a human is intellectual wealth that individuals have precipitated in their long-term learning and life. Most knowledge can exist in people's beliefs and subconsciousness and it is related to individual life experiences, ages, values and other factors. Ruth Williams pointed out that the best way to transfer potential knowledge is to use interpersonal relationships to convey it through perceptual methods in the book "Knowledge Management". The human Library provides a new channel for mining and sharing tacit knowledge that exists in the reader's mind. Contents read by readers in the human library activities are the rich experience of the human books. In the process of dialogue with human books, readers also share their own tacit knowledge. There are mutual input and output of tacit knowledge between them, which reconstructs the inherent tacit knowledge of both parties. The process of borrowing human books is an effective way to realize the development of readers' knowledge resources.

\section{2) Research trends}

There are 19 key words appearing 2 times such as "tacit knowledge transfer", "community library", "virtual community", "library 2.0" and "information ethics" etc. in Chinese. According to the keywords and topic content, the writer predicts that what may become research hotspots are as follows:

a) Tacit knowledge transfer

The focus is no longer knowledge management or sharing, but the transfer of knowledge, especially tacit knowledge. In terms of its implicity, complexity and the difficulty of transfer, Wang Peilin proposed that a meta-cognitive mechanism of tacit knowledge should be established in the human library to make its transfer smoothly [11]; by analyzing the transfer of tacit knowledge in library, he drew a conclusion that the tacit knowledge transfer and personnel interaction complement each other in library. This conclusion will work as a new theoretical guidance for library knowledge management [12]. Tacit knowledge transfer has always been a hotspot and a difficult point in the field of knowledge management, so researches on this topic may attract more scholars' attention.

\section{b) Community Library}

With the continuous deepening of nationwide reading, human library activities may be more widely applied to community-based reading scenarios. As typical cases of community libraries, desert island libraries, rural libraries and automobile libraries serve different community residents. But they face the dilemma of insufficient library resources universally. Practice showed that community libraries not only met the needs of readers to exchange ideas and share knowledge, but also provided environment and resources for the development of human libraries. So they can become an effective way to solve this problem.

\section{c) Virtual community}

According to the concept "Library 2.0", users should participate in resource construction for users are also resources. The virtual community of the human library is the technical innovation and practice in "Internet + digital library". To build a human library in a virtual environment using information technology such as big data, cloud computing, artificial intelligence, Internet of Things and virtual reality has the following advantages: gathering human book resources and reader groups efficiently and effectively, completing knowledge dissemination, sharing and exchange of interaction beyond the limitations of time and space, providing ubiquitous platform, diversified resources and customized services of human resources, etc. The development of researches on virtual community based on human library is in line with the development trend of the technology. The research and exploration will deepen the integration of library science into computer application.

\section{d) Information ethics}

While the human library is booming, it also faces information ethical dilemmas such as privacy disclosure and intellectual property rights violations. In order to achieve 
sustainable development, it is necessary to pay attention to this issue and conduct theoretical discussions on moral constraints, institutional statutes, legal supervision, summarize and analyze the corresponding countermeasures for the subject and object of the activity in practice [13]. With the gradual promotion of human library activities, it's probable that it will trigger widespread concern about information ethics issues.

\section{CONCLUSION}

With the rapid development of information technology, people cannot live without electronic devices. As the number of "phubbers" increases, face-to-face communication decreases for people are more inclined to communicate in the virtual world. As a result, the barriers and prejudice have intensified. As a public welfare institution, the library undertakes the functions of social services and has the responsibility to find solutions for similar problems. The purpose of promoting understanding and tolerance, eliminating barriers and prejudice for human library is in line with this demand, thus it has great potential.

In this paper, CSSCI periodical papers are selected as the data source from 2009 to 2018. The writer conducts statistics and knowledge map analysis on the years, disciplines, core authors, representative journals, fund projects, high-frequency keywords, etc. It provides a certain academic reference for relevant researchers, laying a solid foundation for a greater academic breakthrough, promoting the research and development and providing readers with better quality services in human library.

\section{REFERENCES}

[1] Li Yaqing. Analysis of Chinese Human Library based on Bibliometrics[J]. Journal of Library and Information Sciences in Agriculture, 2013, 25(8):76-81.

[2] Guo Jin. Bibliometric study of Chinese Living Library[J]. Journal of Library and Information Sciences in Agriculture, 2014, 26(5):61-66.

[3] Cao Xia. Bibliometric analysis of Human Library research in China[J]. Journal of Southwest University for Nationalities(Humanities and Social Sciences Edition), 2015, 36(6):236-240.

[4] Li Sumei. Visual analysis of the research status of Human Library in China based on knowledge map[J]. Modern Intelligence, 2015, 35(5): 105-111.

[5] Dong Xiaojun. A literature analysis of the research progress of Human Library in China[J]. Library, 2015(4):41-45.

[6] Qiu Junping. Informatics [M]. Hubei: Wuhan University press, 2007:270-272+192-195.

[7] Zhang Liya. The enlightenment of Living Library to university library service innovation[J]. Journal of Academic Libraries, 2009, 27(5):86-88+103.

[8] Wu Hanhua, Wang Zizhou. A new mode for developing readers' knowledge resources: Living Library [J]. Library Journal, 2010, 29 (09): 21-26+77.

[9] Xu Jing. Living library: The innovation of subject knowledge service in university libraries-Taking Shanghai Jiao tong University Library as an example[J]. Library and Information Service, 2010, 54(1):58-61.

[10] Lai Xuemei. Innovative research on library reading promotion [J]. library, 2015 (6): 21-23.

[11] Wang Peilin. The metacognitive mode of tacit knowledge transfer in Human Library[J]. Library Forum, 2016, 36(4):20-27.

[12] Wang Peilin, Jiang Mengyang. Research on interactive tacit knowledge transfer among library staff [J]. New Century Library, 2017(6): 21-25+34

[13] Wan Wenjuan. Information ethical dilemma of Human Library and its countermeasures[J]. Library, 2015(11):96-99+107 